\title{
Islam and Politics in Central Asia
}

\author{
By Mehrdad Haghayeghi. New York: St. Martin's Press, 1995.
}

The emergence of the five independent and predominantly Muslim statesKazakhstan, Kyrgyzstan, Tajikistan, Turkmenistan, and Uzbekistan-in the afternath of the collapse of the Seviet Union raises the issue of the role of Islan in their future development. Since Islam does not allow a separation of religion and politics, Islamic political parties have already been active, albeit with different intensity, in these countries. None of these countries has had a history of independence; for a long time, they were colonized (their most recent history of colonization goes back to the $1860 \mathrm{~s}$, when the Russians began to conquer and colonize the Centual Asian villages) by czarist Russia, then from 1917 by the communist czars. Consequently, after independence their political elite (for the most part. former conmunists) remain substantially unfamiliar with the practices of democratic governance. As such, even after changing the names of communist parties in their respective countries, they essentially practice authoritarian policies in which fittle or no political pjuralism is tolerated. Therefore, any evolution of democracy in these states in the immediate or middle-range furure is unlikely. However, Kazakhstan and Kyrgyzstan are two exceptions to this rule.

Not coincidentally, both Kazakhstan and Kyrgyzstan top the list of ethnically pluralist states, and their economies are doing well compared to their Centra! Asian counterparts. However, this ethnic pluralism has not only polarized their populations along indigenous and Russian lines but also keeps their leaders from allowing any substantial role for Islamist parties. Uzbekistan. Turkmenistan, and Tajikistan have a lesser problem emanating from ethic pluralism. However, the lion's share of these countries problems stems from the acutely authoritarian nature of their leadership, and, more important, their severe econonic underdevelopment. One has to keep these variables in mind as one reads Mehrdad Hagluyeghits book, Islam and Politics in Central Asia.

Describing the presence of Islan in Central Asia, the atthor states that "the sedentary populations of the oasis enclaves and the tribal populations of the Steppe and the surtounding regions" were differently influenced by Islant. He goes on to observe:

The enormous size and remoteness of the Steppe, the lack of adequate military manpower, the political instability at the heart of the Arab empire, and the absence of 
missionaries early on to spread Islam among the pastoral population have been partially responsible for Islam's relatively poor performance in the tribal regions of Central Asia. As such, Kazakhstan, Kyrgyzstan, and Turkmenistan have developed a mild proclivity toward Islam compared to Tajikistan and Uzbekistan, which have been more thoroughly exposed to its tenets.

This divergent presence of Islam affects the politics of these countries in subtle and not-so-subtle ways-a major theme consistently pursued by the author throughout this volume. The book comprises six chapters. The first one is about the role of Islam during the communist era, from the 1920 s through $1980 \mathrm{~s}$. Changes in Soviet policies toward religions, especially Islam, are examined in chapter 2. The third chapter is about the Islamic revival in the post-Soviet era. Chapter 4 is devoted to the scope of democratic movements in Central Asia. Haghayeghi writes that democratic parties in that region are far from monolithic. Given the opportunities to flourish, these parties promise to "transform the political makeup of some of the republics." Even though the author claims that this chapter is designed "to provide a basis for a comparative assessment of the strength of democracy versus Islam," this particular issue escapes his adequate attention. My guess is that he became so involved in the discussion of political pluralism in the five Central Asian republics - a very important topic that was very well-handled-that toward the end of that chapter he left readers to draw their own conclusions about the previously mentioned comparative assessment.

In chapter 4 the author makes four noteworthy points. First, personal legitimacy is prevalent in all Central Asian countries, primarily because of a pervasive absence of organizational or institutional legitimacy. Second, "the democratic process has been most successful in those republics where the Islamic forces have had a considerably smaller following." Turkmenistan is an exception to this rule, for it has consistently scored poorly both on the scales of democratic and Islamic tendencies. Kazakhstan and Kyrgyzstan are "at the top of the list of the most likely republics to complete the transition to democracy."

Third, the democratic parties of Tajikistan and Uzbekistan have been working on the basis of an informal alliance with the Islamist parties. Consequently, governments in those countries have maintained their opposition to the democratic parties. Fourth, the democratic parties have been opposed to those groups whose nationalistic platforms also underscore religious underpinnings; their acceptance of liberal democratic principles notwithstanding. The last two variables clearly denote the major role that Islam and Islamist parties are likely to play as these polities continue their difficult march toward political pluralism and democracy.

In chapter 5, the author addresses the important subject of government responses to the Islamic resurgence in Central Asia. In this context, Haghayeghi discusses a number of policies and strategies adopted by the governments. The first such strategy is the decision made in 1990 by Kazakhstan's government to establish a separate muftiate. This was clearly aimed at minimizing the influence of the activities of the Islamist "fundamentalists." Tajikistan adopted a similar policy. The second strategy "has been legislation and constitutional provisions designed to define the parameters of religious activities, the violations of which would give the government legal sanctity [sic-I think he meant "sanctions"] to level criminal charges against individuals and religious organizations." Repression and crackdown on religious opposition, the third governmental strategy, is the use of "policies of assimilation of the Islamic forces and appeasement 
of the general public in an effort to stave off the perceived fundamentalist tendencies."

The complexity of Central Asian politics is well-captured by Haghayeghi in chapter 6, "Islam and Ethnic Relations." Factors like old and new ethnic lineage and Stalin's policy of national delimitation played their own distinct roles in complicating the life in the region, and, one would indeed argue, in sowing the seeds of internecine conflict. Pan-Turkism is an overblown centripetal concept, especially when one juxtaposes it against the recurrence of often violent Muslim versus non-Muslim and Muslim versus Muslim conflicts and against strong tendencies related to ethnic separatism. Of these, ethnic separatism poses serious threats to the unity of Kazakhstan and to the continued economic progress of Kyrgyzstan, since its economy relies so heavily on the technical skills and knowledge of the Russian population residing in that country. According to the author, the conflict between Muslim's and non-Muslims in Uzbekistan and Turkmenistan is also problematic, albeit to a lesser degree. The recent reduction of Tajikistan to the status of a "Russian protectorate" only postpones for three to five years the outbreak of a Muslim/non-Muslim conflict. The outbreak of Muslim/Muslim conflicts in different parts of Central Asia also raises questions about the role of Islam as an immediate integrative force.

Haghayeghi makes an important point about the implications for Islam of Pan-Turkism and ethnic separatism in Central Asia. Regarding Pan-Turkism, he writes, whether the growth of this ideology would result in the rise or decline of radical Islam remains a source of controversy. As an anticolonial ideology PanTurkism can only strengthen the anticolonial drive of Islamic "fundamentalism" in Central Asia. However, if the reformist and secular aspects of Pan-Turkism are emphasized by its proponents, it could weaken the growth of radical Islam. The divisive and exclusivistic aspects of ethnic separatism could also "decelerate, and perhaps altogether arrest the development of radical Islam in Central Asia."

In the concluding chapter, Haghayeghi makes a number of significant points about the future role of Islam in Central Asia. First, since the presence of Islam in the Ferghana Valley (which cuts across Tajikistan, Kyrgyzstan, and Uzbekistan) has been pervasive, this region "will continue to set standards for Islamic activism in Central Asia." Second, continued economic growth in these countries would "prevent radical Islam from capitalizing on poverty as a mobilizing anchor." On this point, the author appears to be thoroughly persuaded by the Marxist analysis of the alienation of the proletariat from the bourgeoisie and seems to pay no attention to the spiritual emphasis of radical Islam.

Third, the attitude of the existing governments in Central Asia toward Islam will also determine the political tone and strategies adopted by the Islamist parties. The continued repression of Islamic forces in such countries as Uzbekistan and Tajikistan, as correctly noted by Haghayeghi, "is bound to strengthen the resolve of the Islamic forces and further radicalize their agenda as has indeed been the case in Algeria and Egypt." In countries like Kazakhstan, Kyrgyzstan, and Turkmenistan, where "[r]epression has been a less frequently used method of political control, the chances of averting the radicalization of Islam are considerably better." Fourth, the democratic drive in Central Asia, like the Islamic drive, varies considerably from one republic to the next. Kazakhstan and Kyrgyzstan manifest higher democratic tendencies, while in Tajikistan, Uzbekistan, and Turkmenistan these tendencies remain quite low. 
Finally, the author notes that "the ethnic makeup and orientation of the Central Asian republics" also affect the chances of the emergence of radical Islam. Because of the mild Islamic orientation and the presence of a large Slavic population in Kazakhstan and Kyrgyzstan, chances of the success of radical Islamist forces are not high. In contrast, in Tajikistan and Uzbekistan, where the ratio of Muslim to non-Muslim is large, where govemment repression remains high and democratic tendencies weak, and where the Islamic proclivity is strong, the conditions for the emergence of radical Islam are ripe. Haghayeghi concludes his study with the following propitious note:

So long as democratic electoral methods are chosen, and democratic principles respected, the Islamic forces should be permitted to participate in constructing the political future of this region. The West's implicit or explicit support for those Central Asian regimes that have resorted te repression and violence will undoubtedly produce an adverse effect on the perception of not only the Islanic but also the nascent democratic forces in those republics.

Central Asia is an area about which the West remains relatively ignorant. Even in the aftermath of the implosion of the former Soviet Union. Western leaders remain largely preoccupied with the fate of Russia. Witlout minimizing the significance of Russia. I must note that the West - especially U.S. decision makers - can no longer afford to ignore the importance of the newly independent states of Central Asia. Their acute underdevelopment, dependence on Russia, continued authoritarian rule, and increasing Islanist party activism within their polities make them most likely to experience political turbulence in the coming years. A good place to begin developing an understanding of these states is to focus on their intricate domestic politics. Haghayeghi's book is indeed a major contribution in that direction.

M.E. Ahrari

Professor of National Security \& Strategy Armed Forces Staff College Norfolk, Virginia 